\title{
PENGARUH PASAR SAHAM DUNIA TERHADAP PASAR SAHAM INDONESIA
}

\author{
Elvin Adityara \\ UIN Syarif Hidayatullah Jakarta
}

\begin{abstract}
Influence of Global Stock Markets on Indonesian Stock Market. This research was intended to analyze the causality of the global stock markets to Indonesian stock market. The variables of this research were used stock price indices from nine countries. This research using Granger Causality and VAR from 2004 up to 2010. USA, Japan, and England were selected because those countries had strong economics. The results, there are causality Granger among the global stock markets to Indonesian stock market.The global stock markets that has bidirectional causality were Australian stock market, England stock market, Singapore stock market, and Philipine stock market. Meanwhile, the global stock markets that has uni-directional causality were Japan stock market, USA stock market, Hongkong stock market, and Malaysia stock market.
\end{abstract}

Keywords: granger causality, VAR, global stock markets, Indonesian stock markets

Abstrak. Pengaruh Pasar Saham Dunia Terhadap Pasar Saham Indonesia. Penelitian ini bertujuan untuk menganalisis kausalitas dari pasar saham dunia terhadap pasar saham Indonesia. Variabel yang dipergunakan dalam penelitian ini adalah harga saham dari sembilan negara. Penelitian ini menggunakan uji kausalitas Granger dan VAR dari 2004 sampai dengan 2010. Amerika, Jepang, dan Inggris dipilih karena beberapa negara yang memiliki perekonomian kuat. Hasil yang didapat menunjukkan bahwa terdapat kausalitas antara pasar saham global terhadap pasar saham Indonesia. Pasar saham global yang memiliki kausalitas dua arah ialah pasar saham Australia, Inggri, Singapura, dan Filipina. Sedangkan pasar saham global yang memiliki kausalitas satu arah ialah pasar saham Jepang, Amerika, Hongkong, dan Malaysia.

Kata Kunci: kausalitas granger, VAR, pasar saham global, pasar saham Indonesia 


\section{PENDAHULUAN}

Banyak penelitian dan pendapat dari para ahli yang mengatakan bahwa perekonomian suatu negara banyak dipengaruhi oleh perkembangan perekonomian negara lain. Ekonomi negara yang lebih kuat mempunyai kecenderungan untuk mendominasi negara yang perekonomiannya lebih lemah. Indonesia sebagai salah satu negara berkembang ternyata hingga saat ini masih sangat tergantung pada kondisi perekonomian luar negeri terutama yang berkaitan dengan investasi (Mansur, 2005).

Suatu penelitian yang dilakukan oleh Achsani (2000) tentang bagaimana bursa merespon terhadap shock dari bursa lain, apabila terjadi shock di Amerika Serikat maka bursa - bursa regional tidak akan terlalu meresponnya. Hanya di Singapura, Hong Kong, Jepang, Taiwan, dan New Zealand yang akan langsung merespon, dan respon pun tidak cukup besar. Sebaliknya jika shock di Singapura, Australia atau Hong Kong, secara cepat shock tersebut akan ditransmisikan ke hampir semua bursa saham di Asia Pasifik, termasuk BEI.

Penelitian tentang pengaruh indeks saham bursa global dalam hubungannya dengan indeks harga saham gabungan (IHSG) di Bursa Efek Indonesia dilakukan oleh Mansur (2005). Penelitian ini menggunakan tujuh bursa saham global. Adapun ketujuh bursa saham global tersebut adalah KOSPI yang mewakili bursa saham Korea, HANG SENG yang mewakili bursa saham Hong Kong, NIKKEI 225 yang mewakili bursa saham Jepang, TAIEX yang mewakili bursa saham Taiwan, DOW JONES yang mewakili bursa saham New York, FTSE yang mewakili bursa saham Inggris, dan ASX yang mewakili bursa saham Australia. Hasil penelitian menunjukkan bahwa pengaruh ketujuh indeks bursa saham global secara bersama sama berpengaruh secara signifikan tetapi secara individual hanya indeks bursa KOSPI, NIKKEI 225, TAIEX, dan ASX saja yang mempengaruhi IHSG. Dibandingkan antara ke tujuh pasar modal global yang diteliti, pasar modal regional Asia dan Australia akan lebih mempengaruhi pasar modal Indonesia dibandingkan dengan pengaruh yang diberikan dari pasar modal dari kawasan Eropa dan Amerika.

Karim, M.Z.A dan Gee, C.S (2006) meneliti variabel indeks saham Malaysia (KLCI), Filipina (PSEi), Indonesia (IHSG), Thailand (SET), Hongkong (HANGSENG), Jepang (NIKKEI), China (SSE), dan Amerika Serikat (S\&P 500) 
dengan metode cointegration. Periode penelitian adalah dari tahun 1994-2002. Hasil penelitian menunjukkan bahwa tidak ada hubungan cointegration diantara variabel indeks saham yang diteliti pada saat terjadinya krisis keuangan.

Penelitian selanjutnya dilakukan oleh Wondabio (2006) berkenaan variabel indeks saham Inggris (FTSE), indeks saham Jepang (NIKKEI), Indeks saham Singapura (SSI) dan indeks saham Indonesia (IHSG) dengan metode VAR dan ARCH/GARCH. Periode penelitian adalah dari tahun 2000-2005. Hasil penelitian menunjukkan bahwa FTSE dan NIKKEI ternyata mempunyai pengaruh terhadap JSX, tetapi JSX tidak mempunyai pengaruh terhadap FTSE dan NIKKEI. Ini menunjukkan bahwa kondisi perekonomian negara maju akan berpengaruh terhadap perekonomian negara berkembang. Hubungan FTSE dan NIKKEI terhadap JSX adalah negatif atau berbalik dimana jika FTSE / NIKKEI naik maka JSX turun. Ini menandakan bahwa kenaikan FTSE dan NIKKEI justru menekan JSX. Hal ini dapat diduga adanya pengalihan investasi oleh para investor. JSX dan SSI berhubungan simultan tetapi JSX mempengaruhi SSI secara positif sedangkan SSI mempengaruhi JSX secara negatif. Artinya jika JSX naik maka SSI naik. Sedangkan jika SSI naik maka JSX malah turun.

Dewi (2009) meneliti variabel indeks saham Amerika Serikat (Dow Jones), indeks saham Inggris (FTSE), indeks saham Australia (AORD), indeks saham Hongkong (Hang Seng), indeks saham Jepang (NIKKEI), indeks saham Singapura (Straits Times Index), dan indeks saham Indonesia (IHSG) dengan menggunakan metode Granger dan VAR. Periode penelitian adalah dari tahun 2004-2009. Hasil penelitian menunjukkan bahwa bursa-bursa yang memiliki hubungan kausalitas satu arah secara Granger terhadap bursa Indonesia adalah bursa Amerika, bursa Singapura, bursa Inggris, dan bursa Australia, sedangkan bursa yang memiliki hubungan kausalitas dua arah secara Granger terhadap bursa Indonesia adalah bursa Hongkong dan bursa Jepang. Selain itu dari hasil uji VAR maka ditemukan bahwa bursa Hongkong dan Jepang memiliki pengaruh terhadap bursa Indonesia. Jika dikaitkan dengan teori integrasi pasar modal, maka bursa Hongkong dan bursa Indonesia dikatakan saling terintegrasi. Demikian juga dengan bursa Jepang dan bursa Indonesia dikatakan telah saling 
terintegrasi. Indikator yang mendukung hasil temuan ini adalah adanya data hubungan perekonomian dan perdagangan ekspor dan impor Indonesia terhadap negara tersebut.

Bakrie et al. (2009) meneliti variabel indeks saham Indonesia (IHSG), Amerika Serikat (S\&P 500), Jepang (TOPIX), Singapura (STI), dan China (SSE) dengan metode Autoregressive Distributed Lag (ARDL). Periode penelitian adalah dari bulan Juli tahun 1998 - bulan Desember tahun 2007. Hasil penelitian menunjukkan bahwa indeks saham Indonesia terintegrasi dengan indeks saham dari negara Jepang, Amerika Serikat, Singapura dan China.

Hasibuan (2009) meneliti variabel nilai tukar mata uang, indeks saham Amerika (NASDAQ), indeks saham Taiwan (TAIEX), indeks saham Jepang (NIKKEI) dan indeks saham Korea (KOSPI) terhadap variabel indeks saham Indonesia (IHSG) dengan metode regresi berganda. Periode penelitian adalah daritahun 2001-2008. Hasil penelitian menunjukkan bahwa secara simultan variabel mata uang dan variabel indeks harga saham global (NASDAQ, TAIEX KOSPI, NIKKEI) berpengaruh terhadap pergerakan Indeks Harga Saham Gabungan (IHSG), selain itu, secara parsial variabel nilai tukar mata uang dan indeks harga saham global (NASDAQ, NIKKEI, KOSPI) berpengaruh terhadap pergerakan Indeks Harga Saham Gabungan (IHSG) secara signifikan sedangkan variabel indeks TAIEX berpengaruh tidak signifikan terhadap IHSG.

Mauliano (2009) meneliti variabel Indeks Bursa Asing ( Dow Jones, NYSE, FTSE, STI, NIKKEI, KOSPI, Hang Seng, KLSE), Harga Minyak Dunia, SBI, Inflasi, dan Nilai Tukar Rupiah atas Dollar Amerika terhadap IHSG dengan metode regresi linier berganda. Periode penelitian adalah dari tahun 20042009. Hasil penelitian menunjukkan bahwa indeks Dow Jones, KOSPI, Hang Seng, KLSE, Harga Minyak, SBI dan inflasi lebih dominan dalam mempengaruhi pergerakan IHSG.

Darmawan (2009) meneliti variabel indeks Dow Jones, indeks FTSE, indeks NIKKEI, dan indeks Hang Seng terhadap IHSG dengan metode Granger. Periode penelitian adalah dari tahun 2006-2009. Hasil penelitian menunjukkan bahwa indeks Dow Jones, FTSE dan NIKKEI memiliki pengaruh yang cukup kuat dalam mempengaruhi IHSG pada saat sebelum, ketika, dan sesudah subprime 
mortagage, sedangkan dari ketiga periode penelitian, terlihat bahwa indeks HSI tidak memiliki nilai signifikan yang baik dalam kausalitasnya dengan terhadap IHSG, dengan kata lain HSI tidak memiliki pengaruh terhadap IHSG dan IHSG juga tidak memiliki pengaruh terhadap HSI.

Prio (2010) meneliti variabel indeks saham Malaysia (KLCI), indeks saham Singapura (STI), indeks saham Thailand (SET), indeks saham Filipina (PSE), indeks saham Jepang (NIKKEI), indeks saham Korea (KOSPI), indeks saham Taiwan (TWSE), indeks saham Inggris (FTSE), indeks saham Prancis (CAC), indeks saham Jerman (DAX), indeks saham Amerika Serikat (S\&P), dan variabel makroekonomi (Industrial Production Index, Nilai Tukar, dan Suku Bunga SBI) terhadap IHSG dan LQ 45 dengan metode VAR/VCM dan ARCH/GARCH. Periode pengamatan adalah dari tahun 1994-2009. Hasil penelitian menunjukkan bahwa pengaruh pasar dunia terhadap IHSG dan LQ 45 adalah untuk IHSG pasar saham dunia yang berpengaruh secara signifikan adalah Prancis (CAC), Inggris (FTSE), Jerman (DAX), Malaysia (KLCI), Korea Selatan (KOSPI), Philipina (PSE), Thailand (SET), Amerika Serikat (S\&P), dan Taiwan (TWSE). Pengaruh dari pasar saham Jerman, Korea Selatan, Philipina, dan Amerika Serikat adalah negatif terhadap IHSG, sedangkan sisanya berpengaruh positif terhadap IHSG. Untuk LQ 45 pasar saham dunia yang berpengaruh secara signifikan adalah Prancis (CAC), Inggris (FTSE), Jerman (DAX), Malaysia (KLCI), Korea Selatan (KOSPI), Philipina (PSE), Thailand (SET), Amerika Serikat (S\&P), dan Taiwan (TWSE). Pengaruh dari Jerman, Korea Selatan, Philipina, dan Amerika Serikat adalah negatif terhadap LQ 45. sedangkan sisanya memberikan pengaruh positif terhadap LQ 45. Serta variabel makroekonomi yang mempengaruhi IHSG dan LQ 45 secara signifikan adalah Industrial Production Index, nilai tukar, dan suku bunga SBI. Untuk nilai tukar memberikan pengaruh yang positif terhadap IHSG dan LQ 45. Sedangkan Industrial Production Index dan suku bunga SBI memberikan pengaruh yang negatif terhadap IHSG dan LQ

Bisrya (2010), melakukan penelitian mengenai Analisis Hubungan Kausalitas Pasar Saham Global (HANG SENG, NIKKEI, STI, KOSPI, FTSE, KSE, KLCI, NASDAQ dan ASX) Terhadap Pasar Saham Indonesia (IHSG) (studi kasus 
BEI 1999-2009). Metode yang digunakan adalah Granger Causality. Berdasarkan uji kausalitas dengan menggunakan uji Granger Causality dapat diketahui hubungan yang terjadi antar indeks di negara-negara yang diteliti tidak semuanya saling mempengaruhi kecuali IHSG dengan Hang Seng. Hubungan yang terjadi antara IHSG dan Hang Seng adalah hubungan dua arah (timbal balik). Hubungan IHSG dengan NIKKEI, IHSG dengan STI, IHSG dengan KOSPI, IHSG dengan FTSE, IHSG dengan ASX, IHSG dengan KSE, dan IHSG dengan KLCI adalah hubungan satu arah, dimana NIKKEI, STI, KOSPI, FTSE, KSE, dan ASX mempengaruhi IHSG, namun IHSG tidak memiliki pengaruh terhadap NIKKEI, STI, KOSPI, FTSE, KSE, dan ASX. Hubungan IHSG dengan KLCI dari uji kausalitas Granger menunjukkan bahwa IHSG mempengaruhi KLCI, sedangkan KLCI tidak mempengaruhi IHSG. Penelitian dengan menggunakan uji kausalitas Granger menunjukkan bahwa tidak semua indeks yang diteliti mempunyai hubungan terhadap IHSG. Untuk hubungan IHSG dengan NASDAQ, menunjukkan bahwa tidak ada hubungan baik satu arah maupun dua arah diantara indeks tersebut.

Perbedaan penelitian ini dengan penelitian sebelumnya adalah digunakannya indeks-indeks bursa saham yang terdapat pada wilayah regional Asia Pasifik, Amerika, dan Eropa. Data indeks saham yang digunakan adalah data harian dengan periode penelitian dari tahun 2004-2010.

Tujuan Penelitian ini adalah pertama, untuk menganalisis hubungan yang terjadi antara pasar saham dunia (NIKKEI, NASDAQ, FTSE, ASX, KLCI, HANGSENG, STI, PSEi) dengan pasar saham Indonesia (IHSG); dan kedua, untuk menganalisis pengaruh pasar saham dunia (NIKKEI, NASDAQ, FTSE, ASX, KLCI, HANGSENG, STI, PSEi) terhadap pasar saham Indonesia (IHSG).

\section{METODE}

Populasi dari penelitan ini adalah seluruh aktifitas pergerakan indeks harga saham di negara Indonesia, Jepang, Amerika Serikat, Inggris, Australia, Malaysia, Hongkong, Singapura, dan Filipina mulai dari tahun 2004 sampai tahun 2010. Sampel yang dipilih adalah IHSG, NIKKEI, NASDAQ, FTSE, ASX, KLCI, HANGSENG, STI, PSEi.

Dalam penelitian ini yang akan dipergunakan metode Granger Causality, Vector (VAR), dan model Regresi. Langkah - langkah teknik analisis dalam 
penelitian ini adalah: pertama, Melakukan uji Stasioneritas dan Derajat Integrasi; kedua, Penentuan Lag Lenght, Granger Causality Test. Jika terdapat hubungan dua arah berdasarkan Granger Causality Test, maka metode selanjutnya menggunakan metode VAR. Jika terdapat hubungan satu arah berdasarkan Granger Causality Test, maka metode selanjutnya menggunakan metode Regresi.

\section{PEMBAHASAN}

Uji Stasioneritas data dengan menggunakan uji Augmented Dickey Fuller (ADF) ditemukan bahwa untuk seluruh bursa di dunia adalah stationer pada level. Untuk mendapatkan lag yang optimal dalam melakukan pengujian granger dan VAR terlebih dahulu dilaksanakan pengujian lag yang optimal. Dengan menggunakan software Eviews 6, dapat dilihat hasil dari nilai Final Prediction Error correction (FPE), Akaike Information Criterion (AIC), Schwarz Information Criterion (SC), Hannan-Quinn Information Criterion (HQ), dan Likehood Ratio (LR). Nilai yang minimum dari kriteria-kriteria tersebut akan menentukan dari penentuan lag. Hasil yang diperoleh dari pengolahan data adalah sebagai berikut: pertama, Uji lag IHSG dan NIKKEI. Berdasarkan tabel (lampiran) kriteria LR yang minimum berada pada $\operatorname{lag} 8$, kriteria FPE dan AIC pada $\operatorname{lag} 4$, kriteria SC pada lag 0, dan kriteria HQ pada lag 2. Karena dari beberapa kriteria dalam menentukan lag yang optimal, lag 4 menunjukkan nilai yang minimum. Sehingga lag ini akan digunakan dalam menentukan hubungan kausalitas Granger terhadap IHSG dan NIKKEI. Kedua, Uji lag IHSG dan NASDAQ ditemukan bahwa lag 6 menunjukkan nilai yang minimum. Ketiga, Uji lag IHSG dan FTSE ditemukan bahwa lag 8 menunjukkan nilai yang minimum. Keempat, Uji lag IHSG dan ASX ditemukan bahwa lag 3 menunjukkan nilai yang minimum. Kelima, Uji lag IHSG dan KLCI ditemukan bahwa lag 1 menunjukkan nilai yang minimum. Keenam, Uji lag IHSG dan HANGSENG ditemukan bahwa lag 7 menunjukkan nilai yang minimum. Ketujuh, Uji lag IHSG dan STI ditemukan bahwa lag 8 menunjukkan nilai yang minimum. Kedelapan, Uji lag IHSG dan PSEi ditemukan bahwa lag 1 menunjukkan nilai yang minimum.

Granger Causality merupakan metode untuk melihat bentuk hubungan antar variabel (searah atau dua arah). Dibawah ini adalah hasil pengolahan uji Granger Causality. Hasil Pengolahan IHSG dengan NIKKEI menunjukkan bahwa 
NIKKEI tidak menyebabkan secara Granger terhadap IHSG, hal ini dikarenakan nilai probabilitas $>\alpha 5 \%(0,0929>0,05)$. Selanjutnya, dari uji Granger Causality menunjukkan bahwa IHSG menyebabkan secara Granger terhadap NIKKEI, hal ini dikarenakan nilai probabilitas $<\alpha 5 \%(0,0059<0,05)$. Karena hanya terjadi hubungan satu arah, maka IHSG dan NIKKEI selanjutnya akan menggunakan metode regresi sederhana.

Hasil Pengolahan IHSG dengan NASDAQ menunjukkan bahwa NASDAQ menyebabkan secara Granger terhadap IHSG, hal ini dikarenakan nilai probabilitas < $\alpha 5 \%(0,000<0,05)$. Selanjutnya, dari uji Granger Causality menunjukkan bahwa IHSG tidak menyebabkan secara Granger terhadap NASDAQ, hal ini dikarenakan nilai probabilitas $>\alpha 5 \%(0,4327>0,05)$. Karena hanya terjadi hubungan satu arah, maka IHSG dan NASDAQ selanjutnya akan menggunakan metode regresi sederhana.

Hasil Pengolahan IHSG dengan FTSE menunjukkan bahwa FTSE menyebabkan secara Granger terhadap IHSG, hal ini dikarenakan nilai probabilitas < $\alpha 5 \%(0,00005<0,05)$. Selanjutnya, dari uji Granger Causality menunjukkan bahwa IHSG menyebabkan secara Granger terhadap FTSE, hal ini dikarenakan nilai probabilitas $<\alpha 5 \%(0,0490<0,05)$. Karena terjadi hubungan dua arah, maka IHSG dan FTSE selanjutnya akan menggunakan metode VAR.

Hasil Pengolahan IHSG dengan ASX menunjukkan bahwa ASX menyebabkan secara Granger terhadap IHSG, hal ini dikarenakan nilai probabilitas < $\alpha 5 \%(0,0035<0,05)$. Selanjutnya, dari uji Granger Causality menunjukkan bahwa IHSG menyebabkan secara Granger terhadap ASX, hal ini dikarenakan nilai probabilitas $<\alpha 5 \%(0,0414<0,05)$. Karena terjadi hubungan dua arah, maka IHSG dan ASX selanjutnya akan menggunakan metode VAR.

Hasil Pengolahan IHSG dengan KLCI menunjukkan bahwa KLCI tidak menyebabkan secara Granger terhadap IHSG, hal ini dikarenakan nilai probabilitas $>\alpha 5 \%(0,6014>0,05)$. Selanjutnya, dari uji Granger Causality menunjukkan bahwa IHSG menyebabkan secara Granger terhadap KLCI, hal ini dikarenakan nilai probabilitas $<\alpha 5 \%(0,0100<0,05)$. Karena terjadi hubungan satu arah, maka IHSG dan KLCI selanjutnya akan menggunakan metode regresi sederhana. 
Hasil Pengolahan IHSG dengan HANGSENG menunjukkan bahwa HANGSENG menyebabkan secara Granger terhadap IHSG, hal ini dikarenakan nilai probabilitas $<\alpha 5 \%(0,0053<0,05)$. Selanjutnya, dari uji Granger Causality menunjukkan bahwa IHSG tidak menyebabkan secara Granger terhadap HANGSENG, hal ini dikarenakan nilai probabilitas > $\alpha 5 \%(0,0511>0,05)$. Karena terjadi hubungan satu arah, maka IHSG dan HANGSENG selanjutnya akan menggunakan metode regresi sederhana.

Hasil Pengolahan IHSG dengan STI menunjukkan bahwa STI menyebabkan secara Granger terhadap IHSG, hal ini dikarenakan nilai probabilitas < $\alpha 5 \%(0,0007<0,05)$. Selanjutnya, dari uji Granger Causality menunjukkan bahwa IHSG menyebabkan secara Granger terhadap STI, hal ini dikarenakan nilai probabilitas $<\alpha 5 \%(0,0063<0,05)$. Karena terjadi hubungan dua arah, maka IHSG dan STI selanjutnya akan menggunakan metode VAR

Hasil Pengolahan IHSG dengan PSEi menunjukkan bahwa PSEi menyebabkan secara Granger terhadap IHSG, hal ini dikarenakan nilai probabilitas < $\alpha 5 \%(0,0084<0,05)$. Selanjutnya, dari uji Granger Causality menunjukkan bahwa IHSG menyebabkan secara Granger terhadap PSEi, hal ini dikarenakan nilai probabilitas $<\alpha 5 \%(0,000007<0,05)$. Karena terjadi hubungan dua arah, maka IHSG dan PSEi selanjutnya akan menggunakan metode VAR.

Pada Uji Granger Causality hubungan yang terjadi antara IHSG dan NIKKEI adalah satu arah, dimana IHSG mempengaruhi NIKKEI, maka akan dibuat regresi sederhana antara variabel IHSG dan NIKKEI. Dari Output diatas, maka hasil yang didapat adalah: NIKKEI = - 0,000397 + 0,229632 IHSG Artinya, ketika IHSG bernilai nol, maka NIKKEI akan bernilai -0,000397. Sementara itu, jika IHSG naik satu satuan, maka NIKKEI akan naik sebesar 0,229632 kali.

Hasil pengujian regresi sedehana ditemukan bahwa $\mathrm{IHSG}=0,001137+$ 0,041759 NASDAQ Artinya, ketika NASDAQ bernilai nol, maka IHSG akan bernilai 0,001137. Sementara itu, jika NASDAQ naik satu satuan, maka IHSG akan naik sebesar 0,041759 kali. Hasil regresi ditemukan bahwa KLCI = 0,0000736 + 0,194144 IHSG Artinya, ketika IHSG bernilai nol, maka KLCI akan bernilai -0,0000736. Sementara itu, jika IHSG naik satu satuan, maka KLCI akan 
naik sebesar 0,194144 kali. Hasil uji regresi ditemukan bahwa IHSG =0,001245 + 0,455416 HANGSENG Artinya, ketika HANGSENG bernilai nol, maka IHSG akan bernilai 0,001245. Sementara itu, jika HANGSENG naik satu satuan, maka IHSG akan naik sebesar 0,455416 kali.

Berdasarkan hasil penelitian dengan menggunakan Granger Causality, pasar saham Indonesia memiliki hubungan kausalitas secara Granger dengan beberapa pasar saham dunia. Akan tetapi hubungan kausalitas secara Granger yang terjadi antara variabel-variabel yang diteliti beraneka ragam, yakni dua arah dan satu arah. Beberapa diantaranya yang memiliki kausalitas dua arah secara Granger dengan pasar saham Indonesia adalah pasar saham Australia, Inggris, Singapura dan Filipina. Sedangkan yang memiliki kausalitas satu arah secara Granger dengan pasar saham Indonesia adalah pasar saham Jepang, Amerika Serikat, Hongkong, danMalaysia.

Hubungan yang terjadi antara pasar saham Indonesia dengan beberapa pasar saham dunia yang diteliti diperkuat dengan teori, seperti yang diungkapkan oleh Janakiramanan dan Lamba (1998), pasar saham yang berdekatan secara geografis dan memiliki transaksi ekonomi yang cukup tinggi akan menunjukkan market linkages yang cenderung lebih tinggi.

Dalam penelitian ini, pasar saham dari negara - negara yang berada pada satu regional yang sama yaitu regional Asia Pasifik serta wilayah geografis yang berdekatan dengan negara Indonesia seperti negara Malaysia, Singapura, Filipina, Jepang, Hongkong, dan Australia memiliki hubungan kausalitas secara Granger dengan pasar saham Indonesia. Hal ini dikarenakan keterkaitan pasar saham Indonesia dengan pasar saham luar negeri setelah diperbolehkannya para investor untuk ikut menguasai saham - saham yang tercatat di BEI.

Dalam pasar global saat ini, setiap investor dapat berinvestasi dimanapun dia berada. Investor asing menanamkan modalnya pada bursa di seluruh dunia sehingga antara bursa-bursa di dunia mempunyai keterkaitan secara global. Kejadian dan dinamika harga saham antara satu bursa dengan bursa yang lain saling pengaruh mempengaruhi terutama dengan bursa dari negara-negara yang berdekatan. Selain itu untuk bursa-bursa saham yang berdekatan lokasinya, seringkali memiliki investor yang sama. Selain karena 
kedekatan wilayah geografis, keterkaitan pasar saham Indonesia dengan beberapa pasar saham dunia juga dikarenakan adanya hubungan perekonomian seperti ekspor dan impor.

Variabel indeks saham Jepang (NIKKEI), indeks saham Hongkong (HANGSENG) dan indeks saham Inggris (FTSE) mempunyai kausalitas secara Granger dengan variabel indeks saham Indonesia (IHSG). Hasil penelitian ini sama dengan hasil penelitian dari Dewi (2009) yang menyatakan bahwa indeks saham NIKKEI, HANGSENG, dan FTSE mempunyai kausalitas secara Granger dengan IHSG.

Hubungan Indonesia dengan Jepang sangat erat dalam hal perekonomian. Bagi Indonesia, Jepang merupakan negara mitra dagang terbesar dalam hal ekspor-impor. Selain itu, Jepang juga menempati kedudukan penting diantara negara-negara yang berinvestasi di Indonesia. Dari sisi perdagangan, Jepang tergolong negara yang paling banyak mengimpor udang Indonesia. Volume ekspor udang dari Indonesia ke Jepang pada tahun 2003 sebanyak 52.365 ton. Tahun 2004 turun menjadi 48.624 ton, sedangkan selama periode Januari sampai Maret 2005 sebanyak 10.252 ton atau berkurang 2.247 ton dibandingkan dengan periode yang sama tahun 2004. Perdagangan Indonesia-Jepang pada periode 2003-2007 mengalami pertumbuhan rata-rata 14,35\%. Pada tahun 2008 (Januari-Maret) ekspor non migas Indonesia ke Jepang mencapai US\$ 3,28 milyar, meningkat 7,54\% dibandingkan ekspor tahun 2007 (Januari-Maret) sebesar US\$ 3,05 milyar. Ekspor produk makanan olahan Indonesia ke Jepang dari tahun ke tahun menunjukan peningkatan cukup berarti. Tahun 2007 ekspor makanan olahan Indonesia ke Jepang mencapai US\$ 118,62juta atau meningkat 20,93\% dari US\$ 98,09 juta pada tahun 2006. Periode Januari-Maret 2008 ekspor makanan olahan ke Jepang mencapai US\$29,40 juta, meningkat 11,28\% dibandingkan periode yang sama tahun 2007 sebesar US\$26,42 juta. Sementara itu, Ekpor migas Indonesia ke Jepang selama ini cukup tinggi. Gas dari Indonesia dipakai untuk pembangkit tenaga listrik di Tokyo. Total perdagangan migas Indonesia- Jepang di tahun 2009 mencapai USD 6,628 milyar. Pada tahun 2010 naik 40\% menjadi USD 9.340 milyar. Adapun nilai pedagangan non migas naik53\%, dari USD 21,789 
milyar menjadi USD 33,407 milyar di tahun 2010. Selama 2010, ekspor non moigas ke Jepang menembus angka USD 16,49 milyar. Hal ini menjadikan Jepang sebagai negara tujuan ekspor Indonesia terbesar

Total perdagangan Indonesia-Hong Kong pada tahun 2008 sebesar USD4,2 miliar, naik sebesar 96,1 persen bila dibandingkan tahun 2007 yaitu sebesar USD2,1 miliar. Sedangkan tahun 2009 sedikit mengalami penurunan (8,77 persen) bila dibandingkan tahun sebelumnya, yaitu USD4,2 miliar menjadi USD3,8 miliar. Sementara, Impor Indonesia dari Hong Kong pada tahun 2008 sebesar USD 2,3 miliar atau mengalami kenaikan sebesar 434,9 persen bila dibandingkan periode yang sama pada tahun 2007 yaitu USD 442,6 juta. Sedangkan tahun 2009 turun sebesar 28,28 persen dari USD 2,3 miliar menjadi USD1,7 miliar. Neraca perdagangan Indonesia-Hong Kong selama lima tahun terakhir (2004-2008) selalu menunjukkan posisi surplus bagi Indonesia. Pada tahun 2008, Indonesia memang mengalami defisit sebesar USD 558 juta sehubungan dengan perekonomian HongKong dan dunia yang lesu akibat krisis keuangan global. Sedangkan pada tahun 2009, Indonesia kembali mengalami surplus sebesar USD 413,7. Realisasi investasi Hong Kong di Indonesia selama beberapa tahun terakhir yaitu tahun 2005 dengan nilai USD 396 juta, tahun 2006 senilai USD 187,9 juta, tahun 2007 senilai USD 156,7 juta, serta tahun 2008 senilai USD120,2 juta. Berdasarkan artikel dari antaranews.com, hubungan kerja sama antara Indonesia dan Hongkong cukup erat, terutama yang berkaitan dengan investasi, dan ekspor. Pada akhir tahun 2010, Pemerintah Hong Kong mengalokasikan dana investasi ke Indonesia senilai sekitar 50 miliar dolar AS. Berdasarkan data Kemendag, ekspor Indonesia ke Hong Kong terdiri atas komoditi yang berasal dari sumber daya alam dan manufaktur. Komoditi yg berasal dari sumber daya alam antara lain ikan, kerang-kerangan, kopi, teh, coklat dan rempah-rempah, kertas, serta biji logam. Untuk komoditi ekspor manufaktur Indonesia keHong Kong antara lain benang tenun, kain tekstil, pakaian, sepatu dan alas kaki. Pada tahun 2004, total nilai perdagangan Hongkong dan Indonesia mencapai 22.225 juta dollar Hongkong atau sekitar Rp 26,6 triliun. 
Berdasarkan artikel yang diakses dari www.mediaprofesi.com, Hubungan perdagangan antara Inggris dan Indonesia sangat baik. Total perdagangan Indonesia dengan Inggris pada periode 2004-2009 cenderung mengalami kenaikan. Meski terjadi sedikit penurunan di tahun 2005 sebesar USD 1.936,83 juta dibanding tahun 2004 yang senilai USD 1998,49 juta. Total perdagangan pada tahun-tahun selanjutnya mengalami kenaikan yang cukup signifikan. Pada 2006 senilai USD 1936,83 jutamengalami kenaikan menjadi USD 2.108,15 juta pada tahun 2007 dan menjadi USD 2614,44 juta di tahun 2008. Sementara total perdagangan periode Januari-Oktober 2009 senilai USD 1.937,66 juta. Total ekspor dalam kurun waktu 2004-2008 juga meningkat. Pada 2004, nilai ekspor mencapai USD 1.295,3 juta, mengalami sedikit penurunan menjadi USD 1.291,5 juta pada 2005, kemudian meningkat kembali menjadi USD 1.432,4 juta di 2006, pada 2007 senilai USD 1.454,2 juta dan USD 1.546,9 juta di 2008. Nilai ekspor periode Januari-Desember 2009 mencapai USD 1.431,5 juta. Sementara untuk kinerja impor periode 2004-2009 cenderung fluktuatif, nilai impor tahun 2004 mencapai USD 702,5 juta, turun menjadi USD 645 juta di 2005, kemudian 2006 mencapai USD 552,7 juta, USD653,4 juta (2007) dan USD 1.066,7 juta (2008). Nilai impor periode JanuariDesember 2009 mencapai USD 844 juta. Komoditi ekspor utama Indonesia ke Inggris antara lain adalah sepatu/alas kaki, kayu lapis, tekstil, pakaian jadi, elektronik, mainan anak-anak, kopi, coklat, furnitur dan rempah-rempah. Sementara komoditi ekspor Inggris adalah mesin dan peralatan.

Variabel indeks saham Malaysia (KLCI), indeks saham Singapura (STI), dan indeks saham Australia (ASX) mempunyai kausalitas secara Granger dengan variabel indeks saham Indonesia (IHSG). Hasil penelitian ini sama dengan hasil penelitian dari Bisrya (2010) yang menyatakan bahwa indeks saham KLCI, STI, dan ASX mempunyai kausalitas secaraGranger dengan IHSG.

Sejak tahun 2003, neraca perdagangan Indonesia dan Malaysia selalu surplus untuk Indonesia, walau dengan data yang berbeda. Tahun 2003, Indonesia surplus 1,22 miliar dollar AS, sedangkan Malaysia defisit 834 juta dollar AS. Tahun 2004, Indonesia surplus 1,3 miliar dollar AS dan Malaysia defisit 1,169 miliar dollar AS. Tahun 2005, Indonesia surplus 1,28 miliar dollar 
AS, sedangkan Malaysia defisit 1,07 miliar dollar AS. Tahun 2006, Indonesia surplus 917 juta dollar AS, sedangkan Malaysia defisit 878 juta dollar AS. Neraca Perdagangan Indonesia - Malaysia pada tahun 2008 menunjukkan posisi defisit untuk Malaysia sebesar US\$1,07 milyar. Selama 5 tahun terakhir (20032008), neraca perdagangan menunjukkanposisi surplus bagi Indonesia. Pada periode Januari - Juni 2009, neraca perdagangan menunjukkan posisi defisit bagi Malaysia sebesar US\$ 679,14 juta.

Singapura adalah mitra dagang utama Indonesia ketiga setelah AS dan Jepang. Neraca perdagangan antara Indonesia-Singapura selama 5 tahun 20012005) menunjukkan posisi surplus bagi Indonesia pada 2001,2002, 2003, sedangkan pada tahun 2004 dan 2005 Indonesia mengalami defisit masingmasing sebesar US\$ 84,87 juta dan US\$ 1,63 milyar. Pada tahun 2004 defisit perdagangan migas sebesar US\$2,95 milyar dan pada tahun2005 tercatat sebesar US\$ 5,77 milyar. Dalam perdagangan non-migas (2001-2005) Indonesia tetap surplus. Pada tahun 2005 Indonesia mencatat surplus sebesar US\$ 4,13 milyar sedangkan tahun 2004 tercatat surplus sebesar US\$2,86 milyar. Pada tahun 2006 (Januari - Maret) perdagangan Indonesia defisit sebesar US\$ 67,9 juta. Menurut data statistik yang dikeluarkan oleh IE Singapura, pada tahun 2007, ekspor Indonesia ke Singapura mencapai S\$22,06 Milyar (US\$ 15,76 Milyar) . Sementara itu, ekspor Singapura juga mengalami peningkatan dari S\$ 15,87 milyar pada tahun 2006 menjadi S\$17,24 Milyar pada tahun 2007. Dari tahun 1967 sampai tahun 2005, total investasi Singapura di Indonesia sebesar US\$ 24,58 milyar. Investasi Singapura di Indonesia lebih banyak tersebar di wilayah Batam, Bintan dan Riau, namun Singapura juga memiliki kerjasama yang erat dengan berbagai propinsi di Sumatera. Nilai investor asing khususnya Singapura masih menempatkan posisi tertinggi dalam realisasi investasi di Indonesia selama tahun 2010 dengan nilai US\$ 676,8 juta.

Dalam bidang perdagangan, hubungan Indonesia - Australia berjalan dengan baik dan saling menguntungkan. Pada tahun 2003, perdagangan Indonesia - Australia mencapai A 6,7 milyar (US\$ 4,46 milyar). Nilai ekspor Indonesia mencapai $A \$ 4,053$ milyar (US\$2,65 milyar) sementara nilai impor dari Australia mencapai A 2,762 (US\$1,8 milyar). Pada tahun 2005 ekspor 
Indonesia ke Australia tercatat $A$ \$ 3,654 milyar dan impor senilai $A \$ 3,603$ milyar, tahun 2006 ekspor sebanyak A\$ 4,545 dan impor sebanyak A\$ 4,417 milyar. Pada tahun 2007 ekspor sebesar A 4,883 milyar dan impor A 3,908 milyar. Ekspor utama Indonesia ke Australia antara lain adalah minyak bumi, kertas, produk kayu olahan seperti triplek dan furnitur. Selain itu, di tahun 2009 angka investasi Australia di bidang pertambangan berhasil mencapai nilai A\$ 4 millyar. Variabel indeks saham Filipina (PSEi) mempunyai kausalitas secara Granger dengan variabel indeks saham Indonesia (IHSG). Hasil penelitian ini sama dengan hasil penelitian dari Prio (2010) yang menyatakan banwa variabel PSEi mempunyai pengaruh terhadap variabel IHSG.

Tak bisa dipungkiri bahwa kedekatan geografis dan sosial budaya dapat menjadi faktor pendorong bagi peningkatan perdagangan dan investasi antara Indonesia dan Filipina. Filipina merupakan negara tujuan perdagangan Indonesia dengan komoditas ekspor adalah udang beku, tuna/cakalang beku, ikan segar dan beku, rumput laut kering, dan lain-lain. Ekspor rumput laut Indonesia secara total selalu meningkat pesat dari tahun ke tahun. Pada tahun 2001, ekspor rumput laut ke Filipina mencapai 1,522 ribu ton. Pada tahun 2002, ekpor rumput laut menurun hingga mencapai 1,471 ribu ton. Tetapi, pada tahun 2003, meningkat hingga tiga kali lipat hingga mencapai1,471 ribu ton. Tetapi, pada tahun 2003, meningkat hingga tiga kali lipat hingga mencapai 4573,8 ribu ton. Pada tahun 2009 volume ekspor perdagangan hasil perikanan Indonesia sebanyak 8,13 ribu ton dengan nilai perdagangan sebesar USD 10,23 juta. Untuk volume impor perdagangan hasil perikanan dari Filipina ke Indonesia pada tahun 2009 adalah sebanyak 1,05 ribu ton dengan nilai perdagangan sebesar USD 2,25 juta.

Variabel indeks saham Amerika Serikat (NASDAQ) mempunyai kausalitas secara Granger dengan variabel indeks saham Indonesia (IHSG). Hasil penelitian ini sama dengan hasil penelitian Hasibuan (2009) yang menyatakan bahwa variabel NASDAQ mempunyai pengaruh terhadap variabel IHSG. Hubungan perdagangan antara Indonesia dengan Amerika Serikat cukup baik. Menurut data CIA World Fact Book, hingga tahun 2005 ekspor Indonesia ke AS ditaksir sekitar 9,62 miliar dollar AS per tahun (dengan komoditas utama 
migas, elektronik, kayu lapis, tekstil, dan karet). Sedangkan impor dari AS adalah 4,16 miliar dollar AS (dengan komoditas utama mesin, bahan investasi Amerika Serikat di Indonesia sebesar 1,1 miliar dollar AS. Amerika Serikat merupakan salah satu negara tujuan ekspor utama Indonesia. Nilai total perdagangan Indonesia dengan Amerika Serikat cenderung meningkat sejak tahun 2005 sampai 2008 dan menurun pada tahun 2009. Tahun 2008, nilai total perdagangan Indonesia-Amerika Serikat mencapai 20,9 miliar dollar AS dan kemudian turun menjadi 17,9 milliar dolar AS pada 2009. Sementara selama Januari-Agustus 2010, total perdagangan Indonesia-Amerika Serikat mencapai 15,6 miliar dollar AS, lebih tinggi dibanding periode yang sama tahun 2009 yang nilainya 11,3 miliar dollar AS.

\section{SIMPULAN}

Berdasarkan hasil penelitian dengan menggunakan Granger Causality, pasar saham Indonesia memiliki hubungan kausalitas secara Granger dengan beberapa pasar saham dunia. Akan tetapi hubungan kausalitas secara Granger yang terjadi antara variabel-variabel yang diteliti beraneka ragam, yakni dua arah dan satu arah. Beberapa diantaranya yang memiliki kausalitas dua arah secara Granger dengan pasar saham Indonesia adalah pasar saham Australia, Inggris, Singapura dan Filipina.

Pasar saham Jepang, Amerika Serikat, Hongkong, dan Malaysia memiliki kausalitas satu arah secara Granger dengan pasar saham Indonesia. Hubungan dua arah dan satu arah disebabkan karena hubungan perdagangan khususnya ekspor dan impor serta kegiatan investasi di negara yang dituju. Untuk hubungan dua arah, biasanya antara negara yang satu dengan negara yang lainnya memiliki hubungan perdagangan yang kuat, contohnya adalah ekspor dan impor. Sedangkan untuk hubungan satu arah, biasanya terjadi karena suatu negara bergantung pada negara lainnya, seperti dalam bentuk impor dan investasi.

\section{PUSTAKA ACUAN}

Achsani, N.A. 2000. Mencermati Kejatuhan Indeks Dow Jones: Akankah Indeks BEJ Ikut Terseret? Postdam: University of Potsdam.

Bakri, A.K. et.al. 2009. Financial Integration Between Indonesia And Its Major Trading Partners. MPRA Paper No.17277, 14 September 2009. 
Bisrya, N. 2010. Analisis Hubungan Kausalitas Pasar Saham Global Terhadap Pasar Saham Indonesia (studi kasus BEI 1999-2009). (Skripsi Tidak Dipublikasikan). Jakarta: FEB UIN Syarif Hidayatullah Jakarta.

Darmawan, F.B. 2009. Pengaruh Indeks Dji, Ftse 100, Nikkei 225 dan Hsi Terhadap Indeks Harga Saham Gabungan Sebelum, Ketika, Dan Sesudah Subprime Mortagage Pada Tahun 2006-2009. (Tesis Tidak Dipublikasikan). Yogyakarta: Fakultas Ekonomi dan Bisnis Universitas Gadjah Mada.

Dewi, S. 2009. Analisis Hubungan Kausalitas Bursa Global Terhadap Bursa Efek Indonesia Uji GRANGER Causality dan VAR (Vechtor Autho Regression) Periode Januari 2004-Mei 2009. (Skripsi Tidak Dipublikasikan). Depok: Fakultas Ilmu Sosial dan Politik Universitas Indonesia.

Hasibuan, A.F. 2009. Pengaruh Nilai Tukar Mata Uang Dan Indeks Harga Saham Global Terhadap Pergerakan IHSG. (Tesis Tidak Dipublikasikan). Medan: Universitas Sumatera Utara.

Janakiramanan, S. et.al. 1998. An Empirical Examination of Linkages Between Pacific-Basin Stock Markets. Journal of International Financial Markets, Institutions and Money, Vol 8: 155-173.

Karim, M.Z.A, Gee, C.S. 2006. Stock Market Integration Between Malaysia And Its Major Trading Partners (1994-2002). Applied Econometrics and International Development, Volume 6-3: 203 - 224.

Mansur, M. 2005. Pengaruh Indeks Bursa Global Terhadap Indeks Harga Saham Gabungan (IHSG) Pada Bursa Efek Jakarta (BEJ) Periode Tahun 20002002. Sosiohumaniora, Vol. 7, No. 3, November 2005 : 203 - 21.

Mauliano, D.A. 2009. Analisis Faktor-Faktor Yang Mempengaruhi Pergerakan Indeks Harga Saham Gabungan (IHSG) Di Bursa Efek Indonesia. (Skripsi Tidak Dipublikasikan). Depok: Fakultas Ekonomi Universitas Gunadarma.

Muttaqin, F. 2010. Pengaruh Singapore Stock Index, US Fed Rate, Harga Minyak Mentah Terhadap Kepemilikan Saham Investor Asing dan dampaknya Terhadap IHSG. (Skripsi Tidak Dipublikasikan). Jakarta: FEB UIN Syarif Hidayatullah Jakarta. 
Nachrowi, N.D \& H. Usman. Pendekatan Popular Dan Praktis Ekonometrika untuk analisis Ekonomi Dan Keuangan. Jakarta: Lembaga Penerbit FE UI

Nurdiansyah, D. 2010. Analisis Hubungan Indeks Harga Saham Gabungan (IHSG) Indonesia, Amerika (DJIA), Tokyo (NIKKEI), Hongkong (HSI), dan Korea (KOSPI). (Skripsi Tidak Dipublikasikan). Jakarta: FEB UIN Syarif Hidayatullah Jakarta.

Prio, S.D. 2010. Pengaruh Pasar Saham Dunia Dan Variabel Makroekonomi terhadap IHSG dan LQ 45. (Tesis Tidak Dipublikasikan). Bogor: Institut Pertanian Bogor.

Tan, J.A.R. 1998. Contagion Effects During the Asian Financial Crisis: Some Evidence from Stock Price Data. Pacific Basin Working Paper Series, Center for Pacific Basin Monetary and Economic Studies Economic Research Department Federal Reserve Bank of San Francisco.

Wondabio, L.S. 2006. Analisa Hubungan Index Harga Saham Gabungan (IHSG) Jakarta (JSX), London (FTSE), Tokyo (Nikkei) Dan Singapura (SSI) Pendekatan Model Ekonometri - Autocorrelation Condition Heteroscedasticity (Arch) / Generalized Autocorrelation Condition Heteroscedasticity (Garch) Dan Vector Autoregression (Var) - Suatu Studi Empiris Tahun 2000 - 2005. Simposium Nasional Akuntansi 9 Padang tanggal 23-26 Agustus 2006.

Yuanita, R. 2009. Analisis Hubungan Interdependensi Pasar Saham Indonesia dengan Beberapa Pasar Saham Dunia (Periode 2002-2007). (Skripsi Tidak Dipublikasikan). Depok: Fakultas Ekonomi Universitas Indonesia. 